\title{
Tomato Root Distribution under Drip Irrigation
}

\author{
Maria do Rosário G. Oliveira and António M. Calado \\ Universidade de Évora, Apartado 94, 7001 Évora Codex, Portugal \\ Carlos A. Martins Portas \\ Instituto Superior de Agronomia, Tapada da Ajuda, 1399 Lisbon Codex, Portugal \\ Additional index words. soil water potential, Lycopersicon esculentum
}

\begin{abstract}
Tomato (Lycopersicon esculentum Mill.) root distribution was evaluated by the trench profile wall method at four trickle irrigation regimes (irrigation at soil water potential $-10,-20,-40$, and $-60 \mathrm{kPa}$ ) in a 2-year field trial. Total root length intensity $\left(\mathrm{m}^{\prime} \mathrm{m}^{-2}\right)$, final yield $\left(\mathrm{t} \cdot \mathrm{h} \mathrm{a}^{-1}\right)$ and fruit size $(\mathrm{g} /$ fruit $)$ decreased with decrease in amount of water applied. In both years, tomato water use efficiency $\left(\mathrm{kg} \cdot \mathrm{ha}^{-1} \cdot \mathrm{mm}^{-1}\right)$ was significantly lower with irrigation at $-10 \mathrm{kPa}$ than with any other irrigation regime studied. The largest proportion of tomato roots, $88 \%$ for 1989 and $96 \%$ for 1990 , was found in the top $40 \mathrm{~cm}$ of the soil and rapidly decreased with depth. The high concentration of roots in the 30 to $40 \mathrm{~cm}$ layer was attributed to an horizon with high soil bulk density values, immediately below $40 \mathrm{~cm}$, impeding deeper root penetration. Most roots occurred in the emitter area, close to the plant. In rows $1.5 \mathrm{~m}$ apart, between $12 \%$ and $21 \%$ of total root length was found more than $0.5 \mathrm{~m}$ from the stem, which may have resulted from the interpenetration of roots from plants of adjoining rows.
\end{abstract}

Central and southern Portugal has a Mediterranean climate Csa (Köppen), with dry and warm summers (the mean temperature of the warmest month is $>22^{\circ} \mathrm{C}$ ), low relative humidity, and high insolation (Portas et al., 1986). These conditions favor production of vegetable crops such as tomato since precipitation, which adversely affects quality during fruit maturation, is minimal. However, crop water needs are higher than soil water resources and irrigation must be implemented, especially between June and September.

Drip irrigation can be a solution for sandy soils with low water retention, which are typical of most of these areas. Although automation of the drip systems can reduce production costs, the small soil-root volume per plant under drip irrigation can cause plant stress, Table 1. Physical and chemical characteristics of the soil.

\begin{tabular}{|c|c|c|c|c|c|c|c|c|}
\hline \multirow[b]{2}{*}{$\begin{array}{l}\text { Depth } \\
(\mathrm{cm})\end{array}$} & \multicolumn{3}{|c|}{ Texture } & \multirow{2}{*}{$\begin{array}{c}\text { Bulk } \\
\text { density } \\
\left(\mathrm{g} \cdot \mathrm{cm}^{-3}\right)\end{array}$} & \multirow{2}{*}{$\begin{array}{c}\text { Organic }^{\mathrm{z}} \\
\text { matter } \\
(\%)\end{array}$} & \multirow[b]{2}{*}{$\mathrm{pH}$} & \multirow{2}{*}{$\begin{array}{c}\text { Total }^{\mathrm{y}} \\
\mathrm{P} \\
(\mathrm{ppm})\end{array}$} & \multirow{2}{*}{$\begin{array}{c}\text { Total }^{\mathrm{y}} \\
\mathrm{K} \\
(\mathrm{ppm})\end{array}$} \\
\hline & $\begin{array}{c}\text { Sand } \\
(\%)\end{array}$ & $\begin{array}{l}\text { Silt } \\
(\%)\end{array}$ & $\begin{array}{l}\text { Clay } \\
(\%)\end{array}$ & & & & & \\
\hline$\overline{0-40}$ & 92.3 & 4.3 & 3.4 & 1.62 & 1.24 & 5.5 & 82.9 & 45.7 \\
\hline $41-74$ & 95.4 & 1.4 & 3.2 & 1.75 & 0.40 & 5.5 & 74.6 & 54.8 \\
\hline $75-105$ & 96.6 & 0.6 & 2.8 & --- & 0.21 & 5.6 & 96.0 & 85.5 \\
\hline
\end{tabular}

which in turn

can affect yield, if application of water or nutrients is delayed for even short periods of time (Bar-Yosef et al., 1980). The objective of this investigation was to evaluate the effects of different water regimes on root distribution of processing tomato (Lycopersicon esculentum) with automatic drip irrigation.

\section{Materials and Methods}

Trials were conducted in 1989 and 1990 on a regosol soil (Typic Quarzipsamments) at the Research Station António Teixeira, in Coruche, which represents about 30\% (4000 ha) of the Sorraia Valley area. Soil characteristics and meteorological data during the two years of experimentation are summarized in Tables 1 and 2. Soil water retention curves for the 20 and $60 \mathrm{~cm}$ depth are

Received for publication 17 Apr. 1995. Accepted for publication 12 Sept. 1995. We acknowledge Jules Janick for carefully correcting this text. The cost of publishing this paper was defrayed in part by the payment of page charges. Under postal regulations, this paper therefore must be hereby marked advertisement solely to indicate this fact. presented in Fig. 1. Wilting point $(-1500 \mathrm{kPa})$ and field capacity $(-33 \mathrm{kPa})$ for the $20 \mathrm{~cm}$ depth were 0.031 and $0.20 \mathrm{~cm}^{3} \cdot \mathrm{cm}^{-3}$, respectively. Soil bulk density was measured in undisturbed samples of known volume ( six samples per depth). The experimental design was a randomized block with four irrigation treatments and three replications. The plot sizes were $5 \times 13.5 \mathrm{~m}^{2}$, with nine rows each. Irrigation was applied when soil water potential reached -10 , $-20,-40$, and $-60 \mathrm{kPa}$, corresponding to $85 \%, 65 \%, 55 \%$, and $50 \%$ of soil field capacity, respectively. Root data were analyzed as a split plot with the irrigation treatments as main plots and soil depths as subplots. Data were analyzed by year, using analyses of
Table 2. Meteorological data for 1989 and 1990 cropping season.

\begin{tabular}{lccr}
\hline \hline & Rainfall & \multicolumn{2}{c}{ Temp $\left({ }^{\circ} \mathrm{C}\right)$} \\
\cline { 3 - 4 } Date & $(\mathrm{mm})$ & Max & Min \\
\hline & 1989 & & \\
April & 46.8 & 18.2 & 8.3 \\
May & 92.1 & 25.2 & 11.9 \\
June & 0.8 & 28.4 & 14.1 \\
July & 0.0 & 32.8 & 15.9 \\
Aug. & 0.0 & 29.8 & 15.8 \\
Sept. & 6.9 & 28.3 & 12.1 \\
& 1990 & & \\
April & 96.0 & 19.5 & 8.5 \\
May & 4.4 & 25.8 & 11.8 \\
June & 6.5 & 27.0 & 13.5 \\
July & 1.4 & 32.7 & 15.9 \\
Aug. & 1.0 & 32.3 & 14.8 \\
Sept. & 2.7 & 29.4 & 14.1 \\
\hline
\end{tabular}




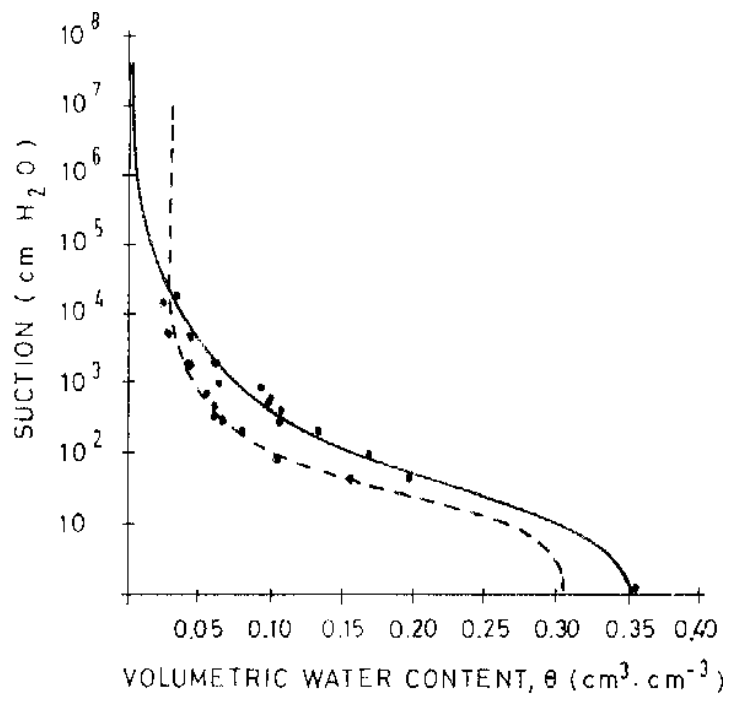

Fig. 1. Soil water retention curves for 20 (-) and 60 (- - -) cm depths.

variance (ANOVA), with mean separation based on LSD at the 5\% level of significance. Irrigation rates and soil depths were regressed against root length intensity data from each year. Goodness of fit was determined by adjusted $R^{2}$ and the significance of regression coefficients.
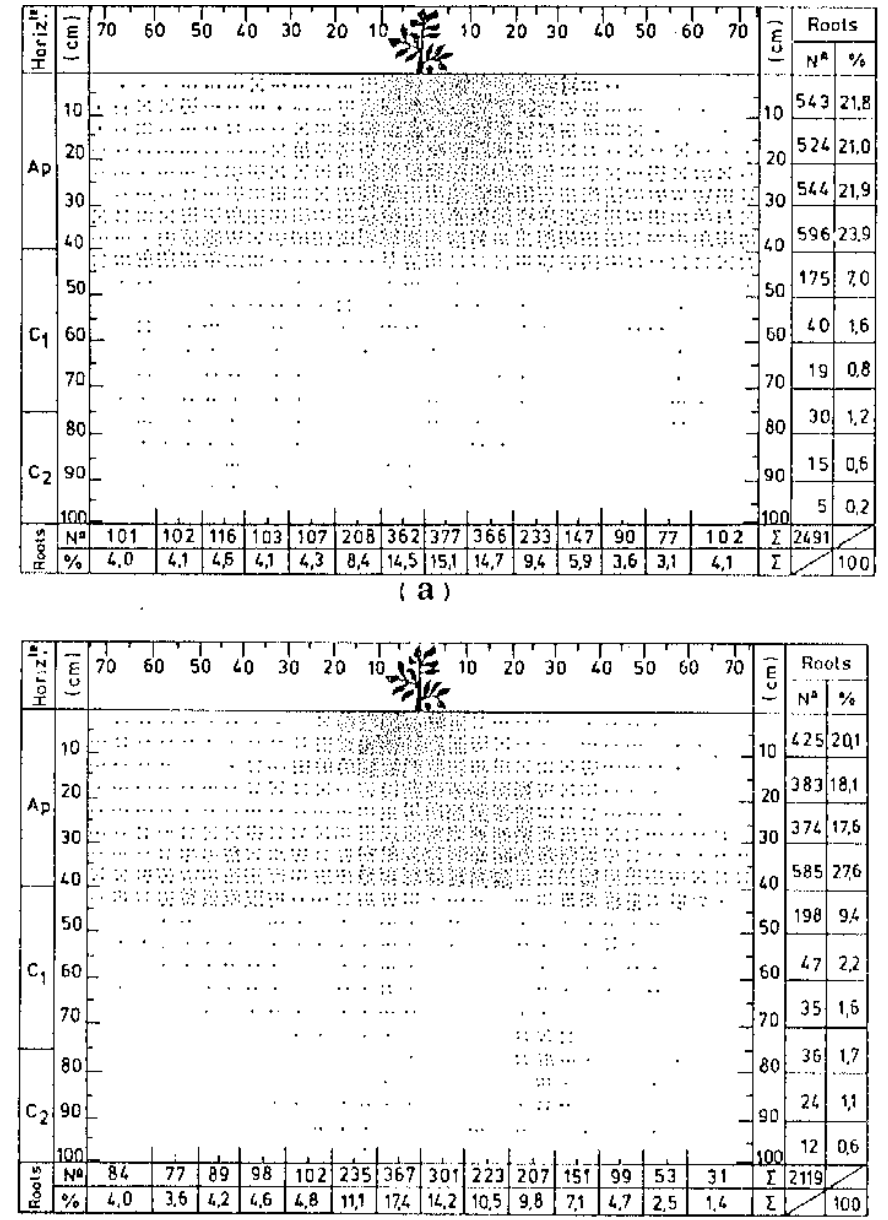

Soil preparation consisted of an initial 30 to $40 \mathrm{~cm}$ deep mouldboard plowing followed by two disc harrow operations to a depth of 10 to $15 \mathrm{~cm}$ for seed bed preparation. 'Rio Grande' tomato cultivar was seeded ( $3 \mathrm{~cm}$ depth) in rows $150 \mathrm{~cm}$ apart and $10 \mathrm{~cm}$ between plants. Soil fertilization in each year was based on soil fertility and plant needs. Before planting, fertilizers as $\mathrm{Ca}\left(\mathrm{NO}_{3}\right)_{2} \cdot 4 \mathrm{H}_{2} \mathrm{O}, \mathrm{MgSO}_{4} \cdot 7 \mathrm{H}_{2} \mathrm{O}, \mathrm{Ca}_{3}\left(\mathrm{PO}_{4}\right)_{2}$ and $\mathrm{K}_{2} \mathrm{SO}_{4}$, at rates $\left(\mathrm{kg} \cdot \mathrm{ha}^{-1}\right)$ for 1989 and 1990, respectively, N(87,44); P(26,26); $\mathrm{K}(498,83)$; $\mathrm{Ca}(129,90)$ and $\mathrm{Mg}(48,48)$ were applied, in a band 15 $\mathrm{cm}$ directly below the row. For fertilizers supplied with irrigation along the growing season as $\mathrm{Ca}\left(\mathrm{NO}_{3}\right)_{2} \bullet 4 \mathrm{H}_{2} \mathrm{O}, \mathrm{KNO}_{3}$ and $\mathrm{H}_{3} \mathrm{PO}_{4}$, the rates in $\mathrm{kg} \cdot \mathrm{ha}^{-1}$ for 1989 and 1990 , respectively, were $\mathrm{N}(152,226) ; \mathrm{P}(28,26) ; \mathrm{K}(116,485)$ and $\mathrm{Ca}(101,55)$. These fertilizers were previously dissolved using tap water, in a tank connected to the irrigation system. The drip irrigation system was automatically controlled by electric tensiometers placed at the $15 \mathrm{~cm}$ depth just below the plants, one for each treatment. All the emitters were located beside the plants and the distance between emitters was 40 $\mathrm{cm}$. The discharge rate was $3 \mathrm{~L} \cdot \mathrm{h}^{-1}$ at a pressure of $1.5 \mathrm{~kg} \cdot \mathrm{cm}^{-2}$. For each treatment, irrigation began at plant thinning and terminated when $75 \%$ of the fruit were red or orange (ready for commercial harvest).

Fruits were harvested in all the plants of six rows ( $5 \mathrm{~m}$ long) for each plot, when $85 \%$ to $90 \%$ of fruit were red or orange, for both years. Fruit were counted and weighed for total yield and medium fruit size determination.
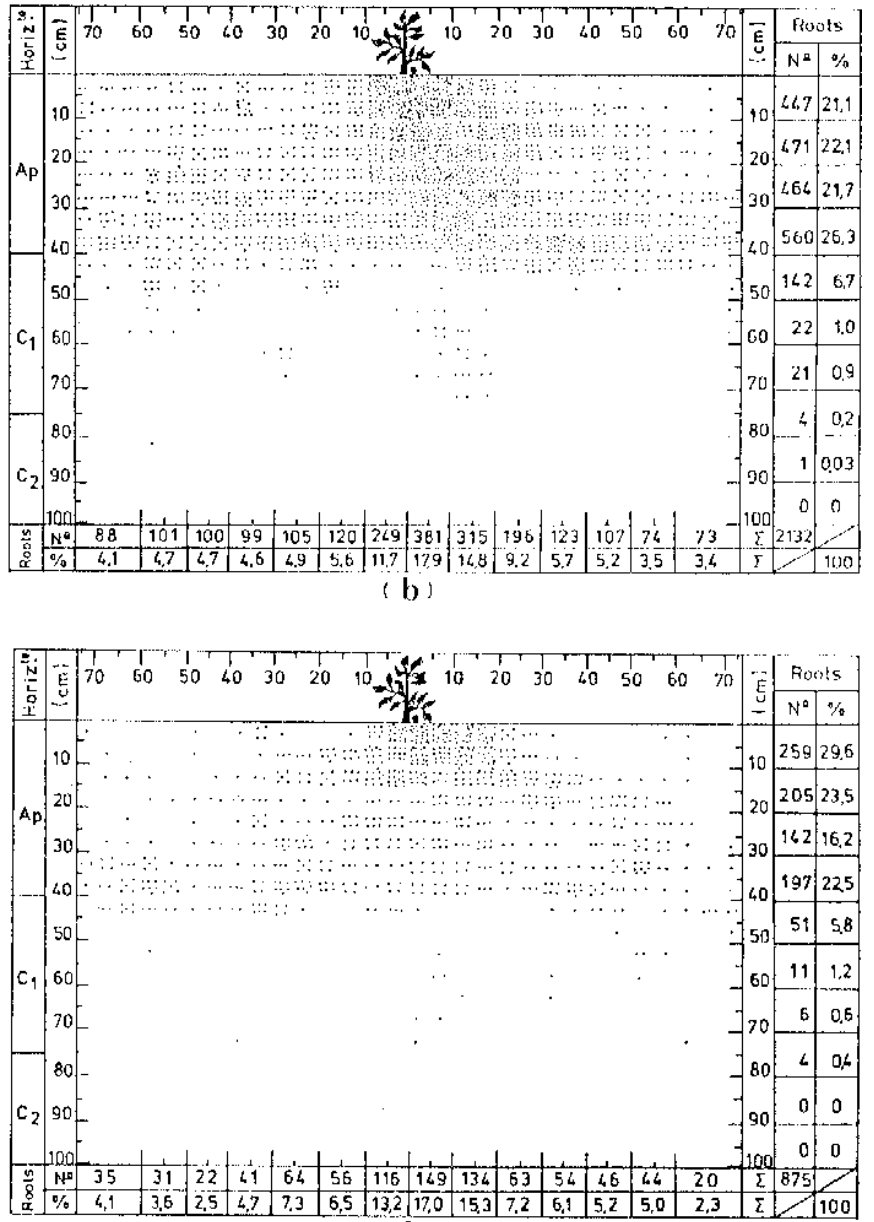

(d)

Fig. 2. Root distribution of tomato at different irrigation regimes: $-10 \mathrm{kPa}(\mathbf{a}) ;-20 \mathrm{kPa}(\mathbf{b}) ;-40 \mathrm{kPa}(\mathbf{c}) ;-60 \mathrm{kPa}(\mathbf{d})(1$ point $=5 \mathrm{~mm}$ visible root length at the profile wall). Drip emitter located beside plant is indicated by 1989. 

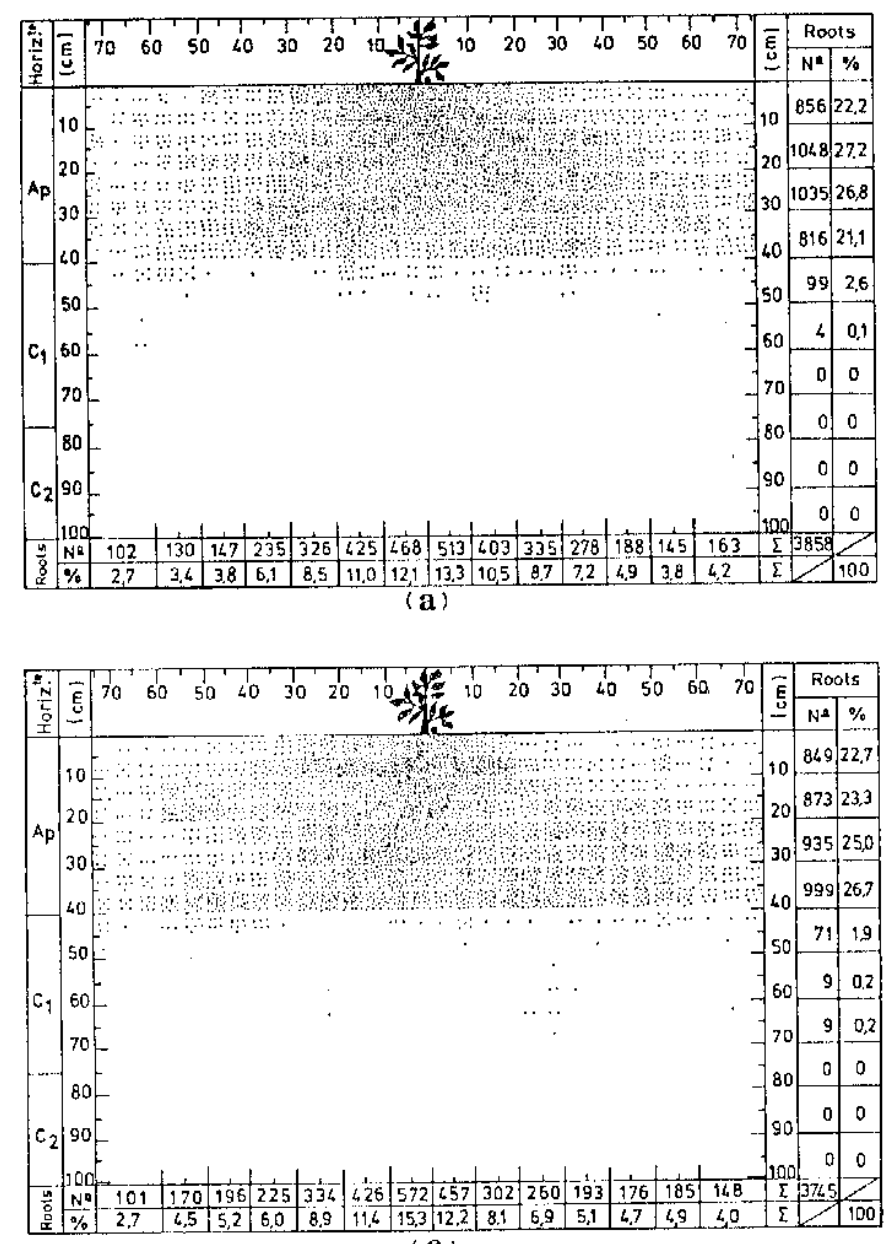

(c)

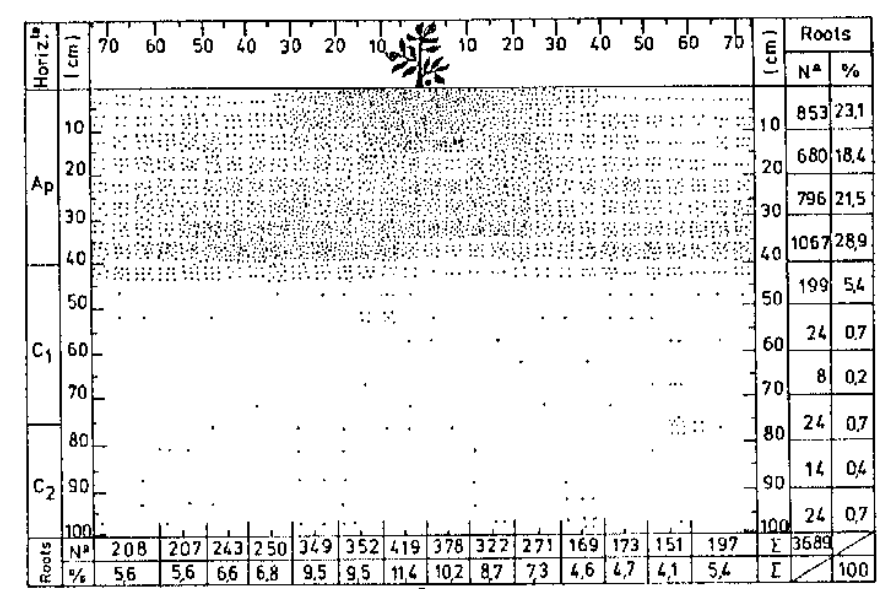

(b)

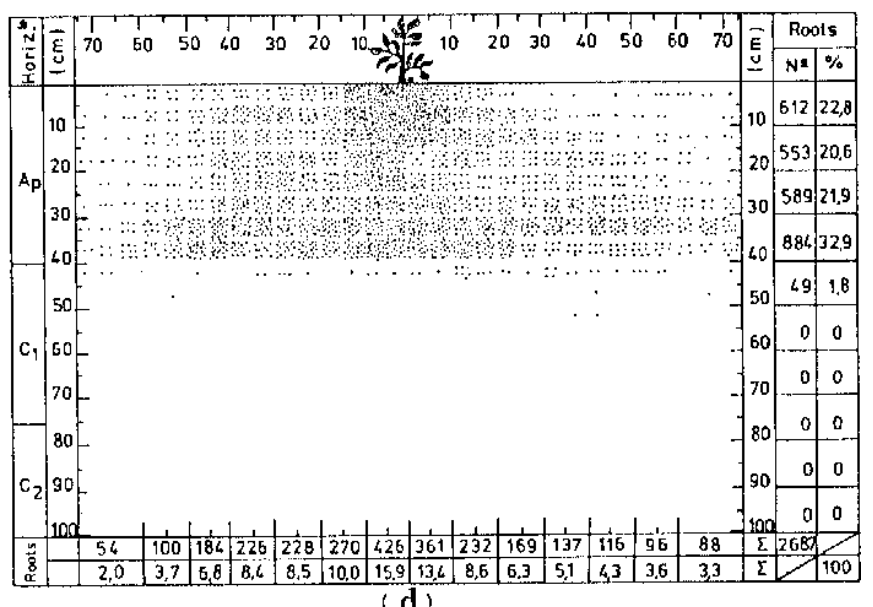
(d)

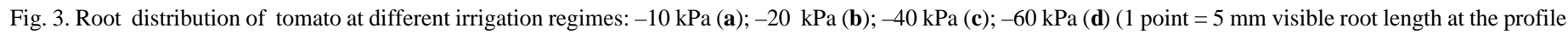
wall). Drip emitter located beside plant is indicated by 1990.

At harvest, three profiles per treatment and replication were opened using the trench profile method (Böhm, 1976) to characterize tomato rooting patterns. A layer of soil that averaged $5 \mathrm{~mm}$ in thickness was washed from a smoothed 1.5-m-wide wall and, then, a metal frame with grids $(5 \times 5 \mathrm{~cm})$ was laid against the profile wall.
The length of roots exposed by washing was estimated by counting the number of 5-mm-long roots in each grid area (Böhm, 1976). The profile wall was located at a distance of $5 \mathrm{~cm}$ from the base of a tomato plant, perpendicular to the row, and extended deeper than the rooting depth. The second and third profiles were made in the

Table 3. Total root length intensity $\left(\mathrm{m} \cdot \mathrm{m}^{-2}\right)$, yield $\left(\mathrm{t} \cdot \mathrm{ha}^{-1}\right)$, mean fruit size ( $\mathrm{g} /$ fruit), and water-use efficiency (WUE) $\left(\mathrm{kg} \cdot \mathrm{ha}^{-1} \cdot \mathrm{mm}^{-1}\right)$ for each irrigation regime.

\begin{tabular}{|c|c|c|c|c|c|}
\hline $\begin{array}{l}\text { Irrigation } \\
\text { treatment }\end{array}$ & $\begin{array}{l}\mathrm{ETR}^{\mathrm{z}} \\
(\mathrm{mm})\end{array}$ & $\begin{array}{c}\text { Root } \\
\text { length } \\
\text { intensity } \\
\left(\mathrm{m} \cdot \mathrm{m}^{-2}\right)\end{array}$ & $\begin{array}{c}\text { Total } \\
\text { yield } \\
\left(\mathrm{t} \cdot \mathrm{ha}^{-1}\right)\end{array}$ & $\begin{array}{c}\text { Mean } \\
\text { fruit } \\
\text { size } \\
\text { (g/fruit) }\end{array}$ & $\begin{array}{c}\text { WUE } \\
\left(\mathrm{kg} \cdot \mathrm{ha}^{-1} \cdot \mathrm{mm}^{-1}\right)\end{array}$ \\
\hline \multicolumn{6}{|c|}{1989} \\
\hline$-10 \mathrm{kPa}$ & 572.9 & 1663.0 & 120.3 & 94.2 & 210.0 \\
\hline$-20 \mathrm{kPa}$ & 428.3 & 1436.4 & 119.3 & 88.2 & 279.0 \\
\hline$-40 \mathrm{kPa}$ & 325.8 & 1415.9 & 89.9 & 77.2 & 276.0 \\
\hline$-60 \mathrm{kPa}$ & 256.2 & 549.0 & 59.9 & 42.5 & 234.0 \\
\hline $\operatorname{LSD}_{0.05}$ & & 169.9 & 12.6 & 4.7 & 36.4 \\
\hline \multicolumn{6}{|c|}{1990} \\
\hline$-10 \mathrm{kPa}$ & 651.0 & 2539.2 & 100.7 & 102.0 & 154.7 \\
\hline$-20 \mathrm{kPa}$ & 446.7 & 2459.4 & 98.3 & 91.7 & 220.1 \\
\hline$-40 \mathrm{kPa}$ & 339.2 & 2496.1 & 75.9 & 68.3 & 223.8 \\
\hline$-60 \mathrm{kPa}$ & 260.5 & 1795.7 & 53.5 & 57.2 & 205.4 \\
\hline $\mathrm{LSD}_{0.05}$ & & 171.3 & 9.6 & 4.5 & 26.8 \\
\hline
\end{tabular}

${ }^{\mathrm{z}} \mathrm{ETR}=$ irrigation + precipitation - drainage. 
Table 4. Relationship between water applied and soil depth having the highest coefficient of determination vs. root length intensity.

\begin{tabular}{|c|c|c|c|c|}
\hline y Parameter & x Parameter & Equation & $R^{2}$ & $P$ value \\
\hline \multirow[t]{4}{*}{ Root length intensity $\left(\mathrm{m} \cdot \mathrm{m}^{-2}\right)$} & Water applied ${ }^{2}(1989)$ & $y=-2601.648+17.095 x-0.017 x^{2}$ & 0.83 & 0.001 \\
\hline & Water applied ${ }^{\mathrm{z}}(1990)$ & $\mathrm{y}=\mathrm{x} /(0.048+0.00031 \mathrm{x})$ & 0.85 & 0.001 \\
\hline & Soil depth (1989) & $y=1041.998 \times e^{-0.063 x}$ & 0.75 & 0.001 \\
\hline & Soil depth (1990) & $y=2694.354 \times e^{-0.084 x}$ & 0.77 & 0.001 \\
\hline
\end{tabular}

${ }^{\mathrm{Z}}$ Irrigation + precipitation - drainage.

same trench and $40 \mathrm{~cm}$ beyond the previous profile, next to another plant-emitter situation. Assuming that one root unit is $0.005 \mathrm{~m}$ long, since $5 \mathrm{~mm}$ of soil has been washed away from a $1.5 \times 1-\mathrm{m}^{2}$ area, a total count of $\mathrm{N}$ units in the whole profile corresponds to a root length per unit of ground surface equal to $(\mathrm{N} \times 0.005) /(1.5 \times$ 0.005). So, root length per unit of soil surface area, root length intensity $\left(\mathrm{m} \cdot \mathrm{m}^{-2}\right)$, was estimated as follows:

Root length intensity $\left(\mathrm{m} \cdot \mathrm{m}^{-2}\right)=\mathrm{N} / 1.5$

where $\mathrm{N}=$ number of points ( 1 point $=5 \mathrm{~mm}$ visible root length $)$.

Rooting intensity pictographs were made by placing dots on gridded paper in positions that corresponded to actual exposed root locations. The same procedure was used for the second year. The number of dots for each grid area corresponds to average values of all the counts made in the same position for each treatment (Figs. 2 and 3$)$.

\section{Results and Discussion}

Total root length per unit of soil surface area was significantly different between irrigation treatments in both years (Table 3).

Table 5. Rooting pattern ${ }^{\mathrm{z}}$ along the soil profile by irrigation regime.

\begin{tabular}{|c|c|c|c|c|}
\hline \multirow{3}{*}{$\begin{array}{l}\text { Depth } \\
(\mathrm{cm})\end{array}$} & \multicolumn{4}{|c|}{ Irrigation treatment } \\
\hline & $-10 \mathrm{KPa}$ & $-20 \mathrm{KPa}$ & $-40 \mathrm{KPa}$ & $-60 \mathrm{KPa}$ \\
\hline & \multicolumn{4}{|c|}{ Root length intensity $\left(\mathrm{m} \cdot \mathrm{m}^{-2}\right)$} \\
\hline \multicolumn{5}{|c|}{1989} \\
\hline $0-10$ & 362.3 & 303.3 & 283.0 & 163.7 \\
\hline $10-20$ & 349.3 & 320.7 & 255.3 & 129.7 \\
\hline $20-30$ & 365.0 & 311.0 & 248.7 & 94.3 \\
\hline $30-40$ & 399.7 & 374.7 & 293.7 & 128.3 \\
\hline $40-50$ & 117.0 & 95.7 & 132.0 & 19.0 \\
\hline $50-60$ & 23.7 & 14.7 & 31.3 & 7.3 \\
\hline $60-70$ & 12.7 & 13.7 & 23.3 & 4.0 \\
\hline $70-80$ & 20.0 & 2.3 & 24.3 & 2.7 \\
\hline $80-90$ & 10.0 & 0.3 & 16.3 & 0.0 \\
\hline $90-100$ & 3.3 & 0.0 & 8.0 & 0.0 \\
\hline \multicolumn{5}{|c|}{1990} \\
\hline $0-10$ & 568.0 & 567.3 & 559.7 & 409.7 \\
\hline $10-20$ & 699.3 & 446.3 & 580.0 & 372.3 \\
\hline $20-30$ & 707.3 & 528.7 & 633.0 & 392.0 \\
\hline $30-40$ & 519.3 & 722.0 & 665.7 & 591.7 \\
\hline $40-50$ & 42.0 & 130.3 & 46.7 & 28.7 \\
\hline $50-60$ & 3.0 & 17.7 & 6.0 & 1.0 \\
\hline $60-70$ & 0.3 & 5.7 & 5.0 & 0.0 \\
\hline $70-80$ & 0.0 & 16.0 & 0.0 & 0.3 \\
\hline $80-90$ & 0.0 & 9.7 & 0.0 & 0.0 \\
\hline $90-100$ & 0.0 & 15.7 & 0.0 & 0.0 \\
\hline
\end{tabular}

${ }_{\mathrm{LSD}}$ at $P=0.05$ for comparison of irrigation treatments within depth: 45.3 for $1989,86.0$ for 1990 . LSD at $P=0.05$ for comparison of depths within irrigation treatment: 44.4 for $1989,88.9$ for 1990.
Total root length intensity decreased as water applied decreased in both trials, which is in agreement with data from Bar-Yosef et al. (1980) and Maynard et al. (1980). Regression models for water applied vs. root length intensity for both years are shown in Table 4. Root growth averaged $1226 \mathrm{~m} \cdot \mathrm{m}^{-2}$ in 1989 and $2323 \mathrm{~m} \cdot \mathrm{m}^{-2}$ in 1990. The greater values in 1990 can be attributed to a better distribution of water during the second year.

In 1989, root length was not significantly different (irrigation at $-20 \mathrm{vs}$. $-40 \mathrm{kPa}$ of soil water potential) with values of about 1400 $\mathrm{m} \cdot \mathrm{m}^{-2}$. Total root length for irrigation at $-20,-40$, and $-60 \mathrm{kPa}$ were $86 \%, 85 \%$, and $33 \%$ respectively of total root length at irrigation at $-10 \mathrm{kPa}$. For the second year only the treatment with irrigation at $-60 \mathrm{kPa}$ was significantly different, with $1796 \mathrm{~m} \cdot \mathrm{m}^{-2}$ of root length intensity as compared with about $2500 \mathrm{~m} \cdot \mathrm{m}^{-2}$ for the other treatments. The rates of total root length for 1990, and for irrigation at $-20,-40$, and $-60 \mathrm{kPa}$ were respectively $97 \%, 98 \%$, and $71 \%$ of total root length obtained with irrigation at $-10 \mathrm{kPa}$. Final yield, fruit size and root growth in both years increased as irrigation increased (Table 3). Although the increase from -20 to $-10 \mathrm{kPa}$ did not raise significantly total yield, the mean fruit size (g/fruit) was significantly higher with irrigation at $-10 \mathrm{kPa}$. A similar increase in fresh fruit yield with increased irrigation water had been reported by Bar-Yosef et al. (1980). The water use efficiency (total yield/real evapotranspiration ETR) (Table 3) in the first year increased with water applied from irrigation at -60 $\mathrm{kPa}\left(234 \mathrm{~kg} \cdot \mathrm{ha}^{-1} \cdot \mathrm{mm}^{-1}\right)$ to irrigation at $-20 \mathrm{kPa}\left(279 \mathrm{~kg} \cdot \mathrm{ha}^{-1} \cdot \mathrm{mm}^{-1}\right)$ but, at $-10 \mathrm{kPa}$, the increase in yield per unit of water applied was significantly lower $\left(210 \mathrm{~kg} \cdot \mathrm{ha}^{-1} \cdot \mathrm{mm}^{-1}\right)$. For the second year, the values for water use efficiency were about $80 \%$ of those obtained in the 1989 experiment, mainly as a result of a lower yield in the second year. The lowest values in water use efficiency were observed in both years, with the highest irrigation regime $(-10$ $\mathrm{kPa}$ ), indicating that irrigation over $-20 \mathrm{kPa}$ must be the object of further studies.

A significant effect of soil depth on root length intensity was observed, and also for the interaction between irrigation treatments and depths the results were significantly different (Table 5). The pattern of root distribution along the soil profile shows, in both years, an exponential decrease in root length intensity with depth (Table 4). Root penetration was restricted at about $40 \mathrm{~cm}$ deep, where an horizon appeared with high soil bulk density values, about $1.75 \mathrm{~g} \cdot \mathrm{cm}^{-3}$. At such soil bulk density values root growth is severely impeded (Oliveira and Portas, 1993). Higher values for root intensity observed in both years for the 30 to $40 \mathrm{~cm}$ layer, indicate that roots tend to proliferate at the depth immediately above a restrictive layer.

A larger proportion of tomato roots, $88 \%$ for 1989 and $96 \%$ for 1990 , were found in the top $40 \mathrm{~cm}$ of soil which agrees with data from Taylor et al. (1970), Bar-Yosef et al. (1980), Maynard et al. (1980), Tan and Fulton (1985), and Sanders et al. (1991). However, our root distribution results do not agree with those from Tindall et al. (1991) who reported that tomato root density under microirrigation did not rapidly decrease with depth. These authors worked with a clay subsoil with presence of large cracks and 
consequently less impedance for root elongation.

The larger proportion of roots found in the area of the emitter, close to the plant, and decreasing with distance from the emitter (Figs. 2 and 3), was also observed by West et al. (1979) and Randall and Locascio (1988). Between $12 \%$ and $21 \%$ of total root length was found more than $0.5 \mathrm{~m}$ from the stem, which can be attributed to interpenetration of roots from plants of adjoining rows. Portas and Dordio (1980) reported that in open fields, at fruit setting stage, tomato root systems of adjoining 1.5-m-apart rows interpenetrate as result of lateral root spreading.

\section{Literature cited}

Bar-Yosef, B., C. Stammers, and B. Sagiv. 1980. Growth of trickle irrigated tomato as related to rooting volume and uptake of $\mathrm{N}$ and water. Agron. J. 72:815-822.

Böhm, W. 1976. In situ estimation of root length at natural soil profiles. J. Agr. Sci. Camb. 87:365-368.

Maynard, D.N., O.A. Lorenz, and V. Magnifico. 1980. Growth and potassium partitioning in tomato. J. Amer. Hort. Sci. 105:79-82.

Oliveira, M.R.G. and C.A.M. Portas. 1993. Acerca do enraizamento das plantas cultivadas. Aspectos pertinentes para as culturas olerícolas, $\mathrm{p}$. 15-49. In: M.F. Ferreira, P.D. Castellane, and M.C.P. Cruz (eds.). Nutriçao e adubaçao de hortaliças. Potafos, Piracicaba, Brasil.
Portas, C.A.M., W. Oliveira , M. Stilwell, A.M. Calado, V. Dias, and H. Altisent. 1986. The tomato processing industry in Portugal. HortScience 21:18-20.

Portas, C.A.M. and J.J.F.B Dordio. 1980. Tomato root systems. A short review with reference on tomatoes for processing. Acta Hort. 100:113124.

Randall, H.C. and S.L. Locascio. 1988. Root growth and water status of trickle irrigated cucumber and tomato. J. Amer. Soc. Hort. Sci. 113:830835.

Riehm,F. 1958. Die ammoniumlaktatessigsoune-methode zur Beslimmung der leichtloslichen phosphonosoure in karbonotholligen Boden. Agrochimica 3.

Sanders, D.C., T.A. Howell, M.M.S. Hile, Hodges, D. Meek , and C.J. Phene. 1989. Yield and quality of processing tomatoes in response to irrigation rate and schedule. J. Amer. Soc. Hort. Sci. 114:904-908.

Tan, C.S. and J.M. Fulton 1985. Water uptake and root distribution by corn and tomato at different depths. HortScience 20:686-688.

Taylor, H.M., M.G. Huck, B. Klepper, and Z.F. Lund. 1970. Measurement of soil-grown roots in a rhizotron. Agron. J. 62: 807-809.

Tindall, J.A., R.B. Beverly, and D.E. Radcliffe. 1991. Mulch effect on soil properties and tomato growth using micro-irrigation. Agron. J. 83:10281034.

West, D.W., I.F. Merrigan, J.A. Jaylor, and G.M. Collins. 1979. Salinity and gradients and growth of tomato plants under drip irrigation. Soil Sci. 127:281-291. 